Research Article

\title{
Awareness of HIV/AIDS infection and ethical concerns amongst dentistry students and auxiliary staff in a hospital setup in Kashmir, India
}

\author{
Asif Yousuf ${ }^{1 *}$, Aasim Farooq Shah ${ }^{1}$, Suhail Majid Jan $^{2}$, Mohsin Sidiq ${ }^{3}$, Irfan Ashraf Baba ${ }^{4}$ \\ ${ }^{1}$ Department of Public Health Dentistry, ${ }^{2}$ Department of Periodontics, ${ }^{3}$ Department of Pedodontics, ${ }^{4}$ Department of \\ Oral Medicine and Radiology, Government Dental College and Hospital, Srinagar, Jammu \& Kashmir -190010, India
}

Received: 05 August 2016

Accepted: 06 September 2016

\section{*Correspondence:}

Dr. Asif Yousuf,

E-mail: asify11@gmail.com

Copyright: (C) the author(s), publisher and licensee Medip Academy. This is an open-access article distributed under the terms of the Creative Commons Attribution Non-Commercial License, which permits unrestricted non-commercial use, distribution, and reproduction in any medium, provided the original work is properly cited.

\begin{abstract}
Background: Human immuno virus infection/ acquired immuno deficiency syndrome (HIV/AIDS) continues to be a major public health issue. HIV/ AIDS may particularly manifest in the oral cavity in the form of oral candidiasis, oral ulcers, non-tender bilateral swelling of the parotid glands and nodular tumours or Kaposi's sarcomas. These oral manifestations are often among the first symptoms of HIV/AIDS which can prove beneficial in the early detection of the disease. The aim of the present study was to assess the awareness of HIV/AIDS infection and related ethical concerns amongst dentistry students and auxiliary staff in a hospital setup in Kashmir.

Methods: This cross sectional survey was conducted among 213 dental health care personnel, which included 34 third year BDS students, 35 Final year BDS Students, 106 Inters and 38 Dental Auxiliary staff comprising of nursing staff and lab technicians. A self-administered questionnaire/ survey instrument consisting of 15 close-ended structured questions to assess knowledge and attitude regarding HIV/AIDS was administered.

Results: The results showed that $70.96 \%$ of 3rd year BDS students, $75.75 \%$ of Final year BDS students, $71.15 \%$ of Interns and $42.10 \%$ of dental auxiliaries had knowledge about HIV infection.

Conclusions: The results of the present study suggest that there is a need of spreading awareness about AIDS among health care provider's including dentists and auxiliary staff for clearing the misconceptions and beliefs regarding the routes of transmission of HIV/ AIDS with the help of CDE/CME Programs and also revising the present syllabus in the curriculum during professional training of Dental graduates and auxiliary staff.
\end{abstract}

Keywords: Dental, HIV/AIDS, Knowledge, Positive attitude

\section{INTRODUCTION}

Human immuno-deficiency virus (HIV) infection is a major public health endemic which is intensely growing and affects every aspect of health care. ${ }^{1}$ HIV has claimed more than 36 million lives worldwide so far. In 2009, the estimated worldwide prevalence of HIV/AIDS was $0.91 \%$ with an estimated 2.5 million people affected in India. ${ }^{2,3}$ HIV/AIDS most commonly manifests in the oral cavity in the form of oral candidiasis, oral ulcers, nontender bilateral swelling of the parotid glands. ${ }^{4}$ The classical presentation of oral lesions is in the form of oral candidiasis followed by herpes simplex virus, ulcerative stomatitis, salivary gland disease, oral hairy leukoplakia, necrotizing gingivitis and Kaposi's sarcoma.

Oral manifestations are the first symptoms of HIV/AIDS and thus can aid in the early detection of the disease. Thus it is a professional and ethical responsibility of every dentist to provide treatment to such patients with HIV infections. The health care professionals are expected to address themselves the critical issues of 
creating community awareness and counseling for HIV infection. ${ }^{6,7}$ Health care sector is perhaps the most obvious perspective for HIV/AIDS related discrimination, stigmatization and denial. ${ }^{8}$ Even today, a small proportion of practitioners and dental students continue to harbour irrational fears regarding occupational risks and actively discriminate against HIV positive patients. It is unethical and unlawful for dental professionals' to refuse to treat HIV positive patients. ${ }^{9}$

The primary prevention for HIV is through health education programs and creating awareness among public. ${ }^{10}$ It is therefore necessary for dental professionals and auxiliary staff to have adequate knowledge to identify these oral lesions which shall aid in early diagnosis and treatment of HIV infection. Every health care professional has an important role to play in detection and referral of suspicious patients to physicians for an early management not only to increase the lifespan of the patient but also to prevent its spread.

However, there are limited studies that have explored the knowledge and attitude of dentists and dental auxiliary staff, particularly in North India. To the best of our knowledge, this is the first study on the knowledge and attitude of dental students toward HIV in Jammu and Kashmir till date. Thus, the aim of the study was to assess the knowledge and attitude of dental students and related ethical concerns toward HIV/AIDS in a government hospital in Kashmir.

\section{METHODS}

This cross sectional survey was conducted among 213 dental health care personnel, which included 34 third year, 35 Final year BDS Students, 106 students doing their post BDS Internship and 38 Dental Auxiliary staff which included nursing staff and lab technicians of Government Dental College and Hospital, Srinagar. Ethical approval was obtained from Institutional Review Board of the concerned dental college and an informed verbal consent was acquired from all the subjects who were willing to participate. The participation was voluntary after the aim of the present study was communicated to the participants.

A self-administered, pretested questionnaire was taken which comprised of 15 questions which were according to the WHO, Knowledge, Attitude, Behaviour and practices (KABP) questionnaire, to assess the knowledge and attitude of the participants. ${ }^{11}$

The survey instrument was a close-ended, structured questionnaire to assess knowledge and attitude regarding HIV/AIDS. The questions were related to the modes and routes of transmission, precautions of AIDS and most of the questions were bipolar questions, having options as Yes/No and the remaining questions were multiple choice questions. After obtaining informed verbal consent, the questionnaire was distributed amongst all the dental students and the dental auxiliary staff which were to be filled and returned to the investigator after completion on the same day. The respondents were ensured that anonymity will be maintained for the responses at all times. Only completely filled questionnaires were selected for the analysis which included responses from 31 third year BDS students, 33 Final year BDS Students, 104 Interns and 38 Dental Auxiliary staff. The remaining 7 questionnaires were incompletely filled and were rejected and not included for the analysis.

The data collected was entered in Microsoft excel sheet and analyzed for simple statistics as mean and percentage.

\section{RESULTS}

The results are comprehensively presented in Table 1. Overall, $70.96 \%$ of $3^{\text {rd }}$ year BDS students, $75.75 \%$ of Final year BDS students, $71.15 \%$ of Interns and $42.10 \%$ of auxiliaries had knowledge about HIV infection. Sixty seven percent intern respondents have mentioned blood as the modes of transmission for HIV. Ninety one percent intern respondents were of the opinion that Dentists can get infected from HIV patients. Majority of interns $(71.15 \%)$ believed that HIV infected patients can be treated in a Dental setting and $63.46 \%$ of the interns were of the belief that there was no ethical right to reject treating an HIV patient. Majority of $3^{\text {rd }}$ year BDS students $(78.78 \%)$ as well as interns $(80.76 \%)$ believed that it was important to uphold the confidentiality of a patient with HIV positive status.

\section{DISCUSSION}

The chances of acquiring HIV infection in the dental setting during dental treatment is high as most of the HIV infected patients are unaware of their disease status. It is necessary for dental professionals and supporting staff to have adequate knowledge about HIV infection/ AIDS. They have an important role to play in early detection and referral of suspicious patients for their early management. It is the ethical and moral responsibility of all dental professionals to treat HIV positive patients in the same way that treat all other patients. The present cross sectional survey was conducted to assess knowledge and attitude of dental students and auxiliaries toward HIV/AIDS and the related ethical concerns in a government hospital setup in Jammu and Kashmir.

The present study showed that among all dental students, a total of $72.02 \%$ were having fair knowledge about AIDS. Amongst these, Final year BDS students $75.75 \%$ were having a better knowledge than the other two groups. The reason might be attributed to the existence of topics related to AIDS in their curriculum. The results of present study were conflicting to a study conducted in Delhi, where majority $(96.3 \%)$ of health care providers had correct knowledge regarding AIDS and $69.7 \%$ respondents could tell correctly about HIV. ${ }^{12}$ In the 
present study, less than half of the dental auxiliaries were unaware about HIV/AIDS. This could be attributed to the absence of related topics in their curriculum during their study course.

Table 1: Attitude and practices of the participants towards HIV/AIDS.

\begin{tabular}{|c|c|c|c|c|c|}
\hline \multirow[t]{3}{*}{ Questions } & \multirow[t]{3}{*}{ Options } & \multicolumn{4}{|l|}{$n=206$} \\
\hline & & $3^{\text {rd }}$ year & Final Year & Interns & $\begin{array}{l}\text { Dental } \\
\text { Auxiliaries }\end{array}$ \\
\hline & & $\mathbf{n}=\mathbf{3 1}$ & $\mathbf{n}=\mathbf{3 3}$ & $\mathrm{n}=104$ & $n=38$ \\
\hline \multirow[t]{2}{*}{ Do you know about HIV infection? } & Yes & $22(70.96 \%)$ & $25(75.75 \%)$ & $74(71.15 \%)$ & $16(42.10 \%)$ \\
\hline & No & $9(29.03 \%)$ & $8(24.24 \%)$ & $30(28.84 \%)$ & $22(57.89 \%)$ \\
\hline \multirow{2}{*}{$\begin{array}{l}\text { Is the curriculum enough for } \\
\text { management of HIV patient? }\end{array}$} & Yes & $15(48.38 \%)$ & $19(57.57 \%)$ & $63(60.57 \%)$ & $14(36.84 \%)$ \\
\hline & No & $16(52.61 \%)$ & $14(42.42 \%)$ & $41(39.42 \%)$ & $24(63.15 \%)$ \\
\hline \multirow{6}{*}{$\begin{array}{l}\text { What is the main mode of } \\
\text { transmission of HIV infection? }\end{array}$} & Blood & $12(38.70 \%)$ & $15(45.45 \%)$ & $70(67.30 \%)$ & $10(26.31 \%)$ \\
\hline & Saliva & $5(16.12 \%)$ & $2(6.06 \%)$ & $5(4.80 \%)$ & $5(13.15 \%)$ \\
\hline & Breast Milk & $1(3.22 \%)$ & $1(3.03 \%)$ & $3(2.88 \%)$ & $2(5.26 \%)$ \\
\hline & Mucous & $2(6.45 \%)$ & $1(3.03 \%)$ & $4(3.84 \%)$ & $3(7.89 \%)$ \\
\hline & Tears & $1(3.22 \%)$ & $2(6.06 \%)$ & $6(5.76 \%)$ & $3(7.89 \%)$ \\
\hline & Genital Secretions & $10(32.25 \%)$ & $13(39.39 \%)$ & $16(15.38 \%)$ & $15(39.47 \%)$ \\
\hline \multirow{4}{*}{$\begin{array}{l}\text { What is the route of transmission of } \\
\text { HIV infection? }\end{array}$} & Injection & $5(16.12 \%)$ & $3(9.09 \%)$ & $8(7.69 \%)$ & $6(15.78 \%)$ \\
\hline & Blood transfusion & $4(12.90 \%)$ & $2(6.06 \%)$ & $1(0.96 \%)$ & $8(21.05 \%)$ \\
\hline & Sexual intercourse & $8(25.80 \%)$ & $3(9.09 \%)$ & $2(1.92 \%)$ & $5(13.15 \%)$ \\
\hline & All of the above & $14(45.16 \%)$ & $25(75.75 \%)$ & $93(89.42 \%)$ & $19(50.00 \%)$ \\
\hline \multirow{2}{*}{$\begin{array}{l}\text { Do you think Dentists can get } \\
\text { infected from HIV patients? }\end{array}$} & Yes & $19(61.29 \%)$ & $24(72.72 \%)$ & $95(91.34 \%)$ & $15(39.47 \%)$ \\
\hline & No & $12(38.70 \%)$ & $9(27.27 \%)$ & $9(8.65 \%)$ & $23(60.52 \%)$ \\
\hline \multirow{2}{*}{$\begin{array}{l}\text { Can Dentists prevent HIV infection } \\
\text { following proper barrier techniques? }\end{array}$} & Yes & $23(74.19 \%)$ & $27(81.81 \%)$ & $90(86.53 \%)$ & $20(52.63 \%)$ \\
\hline & No & $8(25.80 \%)$ & $6(18.18 \%)$ & $14(13.46 \%)$ & $18(47.36 \%)$ \\
\hline \multirow{6}{*}{$\begin{array}{l}\text { What has the possibility of } \\
\text { transferring HIV infection? }\end{array}$} & Kissing & $2(6.45 \%)$ & $3(9.09 \%)$ & $3(2.88 \%)$ & $6(15.78 \%)$ \\
\hline & Hand Shaking & $2(6.45 \%)$ & $2(6.06 \%)$ & $4(3.84 \%)$ & $3(7.89 \%)$ \\
\hline & Using public & $1(3.22 \%)$ & $1(3.03 \%)$ & $3(2.88 \%)$ & $2(5.26 \%)$ \\
\hline & toilets & $16(52.61 \%)$ & $20(60.60 \%)$ & $88(84.61 \%)$ & $18(47.36 \%)$ \\
\hline & Sharing razors & $2(6.45 \%)$ & $1(3.03 \%)$ & $1(0.96 \%)$ & $1(2.63 \%)$ \\
\hline & $\begin{array}{l}\text { Sharing Utensils } \\
\text { None }\end{array}$ & $8(25.80 \%)$ & $6(18.18 \%)$ & $5(4.80 \%)$ & $8(21.05 \%)$ \\
\hline \multirow{2}{*}{$\begin{array}{l}\text { Can aerosols produced during dental } \\
\text { treatment on HIV infectious patients } \\
\text { transmit HIV? }\end{array}$} & Yes & $21(67.74 \%)$ & $24(72.72 \%)$ & $81(77.88 \%)$ & $15(39.47 \%)$ \\
\hline & No & $10(32.25 \%)$ & $9(27.27 \%)$ & $23(22.11 \%)$ & $23(60.52 \%)$ \\
\hline \multirow[t]{6}{*}{ Oral manifestations of HIV include: } & Kaposi Sarcoma & $2(6.45 \%)$ & $1(3.03 \%)$ & $8(7.69 \%)$ & $3(7.89 \%)$ \\
\hline & Candidiasis & $2(6.45 \%)$ & $3(9.09 \%)$ & $4(3.84 \%)$ & $6(15.78 \%)$ \\
\hline & ANUG & $3(9.67 \%)$ & $2(6.06 \%)$ & $12(11.53 \%)$ & $6(15.78 \%)$ \\
\hline & Hairy leukoplakia & $4(12.90 \%)$ & $3(9.09 \%)$ & $4(3.84 \%)$ & $4(10.52 \%)$ \\
\hline & Herpetic Infections & $2(6.45 \%)$ & $1(3.03 \%)$ & $2(1.92 \%)$ & $11(28.94 \%)$ \\
\hline & All of the above & $18(58.06 \%)$ & $23(69.69 \%)$ & $74(71.15 \%)$ & $8(21.05 \%)$ \\
\hline \multirow{2}{*}{$\begin{array}{l}\text { Do you think an HIV infected patient } \\
\text { can be treated in a Dental setting? }\end{array}$} & Yes & $18(58.06 \%)$ & $21(63.63 \%)$ & $74(71.15 \%)$ & $15(39.47 \%)$ \\
\hline & No & $13(41.93 \%)$ & $12(36.36 \%)$ & $30(28.84 \%)$ & $23(60.52 \%)$ \\
\hline \multirow{2}{*}{$\begin{array}{l}\text { Knowing that a patient is HIV } \\
\text { infected, will you be willing to treat } \\
\text { the patient? }\end{array}$} & Yes & $23(74.19 \%)$ & $21(63.63 \%)$ & $60(57.69 \%)$ & $12(31.57 \%)$ \\
\hline & No & $8(25.80 \%)$ & $12(36.36 \%)$ & $44(42.30 \%)$ & $26(68.42 \%)$ \\
\hline \multirow{2}{*}{$\begin{array}{l}\text { Do you think patients should give } \\
\text { proper medical history of HIV? }\end{array}$} & Yes & $24(77.41 \%)$ & $26(78.78 \%)$ & $88(84.61 \%)$ & $24(63.15 \%)$ \\
\hline & No & $7(22.58 \%)$ & $7(21.21 \%)$ & $16(15.38 \%)$ & $14(36.84 \%)$ \\
\hline \multirow{2}{*}{$\begin{array}{l}\text { Do you think HIV positive dentist/ } \\
\text { Health Care professional shall inform } \\
\text { his patient about his health state? }\end{array}$} & Yes & $19(61.29 \%)$ & $23(69.69 \%)$ & $77(74.03 \%)$ & $15(39.47 \%)$ \\
\hline & No & $12(38.70 \%)$ & $10(30.30 \%)$ & $27(25.96 \%)$ & $23(60.52 \%)$ \\
\hline \multirow{2}{*}{$\begin{array}{l}\text { Does a dentist have an ethical right to } \\
\text { reject treating an HIV patient? }\end{array}$} & Yes & $19(61.29 \%)$ & $17(51.51 \%)$ & $38(36.53 \%)$ & $29(76.31 \%)$ \\
\hline & No & $12(38.70 \%)$ & $16(48.48 \%)$ & $66(63.46 \%)$ & $09(23.68 \%)$ \\
\hline \multirow{2}{*}{$\begin{array}{l}\text { Do you think it is important to uphold } \\
\text { the confidentiality of a patient with } \\
\text { HIV positive status? }\end{array}$} & Yes & $22(70.96 \%)$ & $26(78.78 \%)$ & $84(80.76 \%)$ & $19(50.00 \%)$ \\
\hline & No & $9(29.03 \%)$ & $8(24.24 \%)$ & $20(19.23 \%)$ & $19(50.00 \%)$ \\
\hline
\end{tabular}


The results were contradictory with another study conducted in Nigeria, where it was reported that $80.3 \%$ registered nurses had knowledge about HIV/AIDS. ${ }^{13}$ The results were also conflicting to the previous studies where less number of dentists, nurses, lab technicians and Class IV employees had excellent knowledge about the modes of transmission of HIV/AIDS. ${ }^{14-17}$ While similar findings were observed in Japanese dental students who had an average knowledge about this. ${ }^{18}$ The results are also conflicting with a previous study among Iranian dental students, who were found to have excellent knowledge. ${ }^{19}$

When asked about whether the curriculum related to the management of HIV/AIDS, the poor response amongst almost all the groups was observed. It is recommended that curriculum should be revised and included focusing on the clinical management of HIV for both BDS as well as Dental auxiliary courses.

Overall, $67.30 \%$ of Intern respondents in the present study mentioned blood as the mode of transmission for HIV and $89.42 \%$ of the interns correctly mentioned injection, blood transfusion as well as sexual intercourse as the routes of transmission of HIV infection. These results were conflicting to a study conducted by Bishop et al where it was reported that $98 \%$ of doctors, dentists and nurses were of the opinion that sex and needle sharing were routes of transmission of HIV. ${ }^{20}$ Whereas Goel et al in a previous study on nursing professionals, had found that $96.1 \%$ of the respondents were knowledgeable about sexual intercourse, $87.8 \%$ about blood and blood products and $79 \%$ about needles, syringes and razors as a route of transmission. $^{21}$

In the present study it was observed that only negligible subjects from all the groups were of the opinion that HIV infection could be transmitted by sharing utensils. The reason could be attributed to the contact of saliva with mucus membrane which might lead to transmission of the infection. Also, less than $7 \%$ dental students believed that kissing, hand shaking and using public toilets could possibly transfer HIV infections.

In contrast more than $15 \%$ of dental auxiliary staff believed that these could transmit HIV infections showing the lack of knowledge in their group. It was also observed in the present study that less number of subjects believed that HIV infection could be transmitted through saliva which was opposing to a study conducted amongst 250 Nigerian dentists, where $40.8 \%$ mistakenly believed that HIV could be transmitted through saliva. ${ }^{22}$

The present study found that majority of the dental interns believed that dentists could acquire infection from HIV patient. The results are similar to previous study conducted by McCarthy et al where it was seen that HIV infection transmitted mostly through needle stick injuries. ${ }^{23}$ More than $80 \%$ of Final year students and Interns were of the opinion that dentists can prevent HIV infection following proper barrier techniques. The results were similar to a study, where it was observed that both dental staff and patients can be protected best by their compliance with standard infection control precautions and using protective equipment and techniques ${ }^{24}$ and following the universal barrier precautions in the hospital setup. $^{25}$

The present study showed that $41.93 \% 3^{\text {rd }}$ year BDS students, $36.36 \%$ Final year BDS students, $28.84 \%$ Interns and $60.52 \%$ of dental auxiliaries believed that HIV infected patient could not be treated in a Dental setting. While similar findings have been reported previously, where dentists were reluctant to and denied treatment of patients with HIV/ AIDS. ${ }^{26}$ It has become compulsory for a dentist to have adequate knowledge about HIV/AIDS. The present study focused on assessing the knowledge and attitude of dental students, interns and dental auxiliaries. It is vital for dental students to have adequate knowledge about HIV, as it increases their confidence in approaching and handling of HIV patients. $^{27}$

There has been lack of knowledge about transmission of HIV among health care professionals in India. This has led to refusal of treatment to persons living with HIV. ${ }^{28}$ inadequate knowledge can act as a barrier to appropriate treatment of HIV positive patients in healthcare settings. Similar findings have been published in other parts of the world. ${ }^{14,29,30}$ The lack of knowledge regarding HIV/AIDS may hamper and limit the dentists and dental auxiliary staff from treating such patients. Even though it is widely accepted that health care professional play a crucial role in prevention and control of HIV/AIDS, attention is being given to assess knowledge and attitude of health care professionals for overcoming ignorance and spreading awareness. $^{31}$

The present study revealed that only about $70 \%$ of final year BDS students and interns were aware about the correct oral manifestations of HIV/ AIDS. In contrast less number of dental auxiliaries was aware of it. Majority of $3^{\text {rd }}$ year BDS students $(78.78 \%)$ as well as interns $(80.76 \%)$ believed that it was important to uphold the confidentiality of a patient with HIV positive status. The inclusion of topics like ethics, medical jurisprudence and ethical obligations of dentists towards the community should be included in the syllabi as Dentists have a professional and ethical duty to treat all patients alike including HIV patients. ${ }^{7}$

\section{CONCLUSION}

It was concluded that knowledge about the HIV/AIDS was not up to the satisfactory level among the students with poor level of knowledge regarding modes of transmission among the dental auxiliary staff.

It is thereby recommended that Continuing Dental Education Programs and Continuing Medical Education programs on management of HIV patients and ethical 
concerns and duties of Health Care providers to HIV/ AIDS patients should be conducted on regular basis.

As health care providers and auxiliaries play an important role in the society for the spread of knowledge about routes of transmission of HIV, updated curriculum related to the modes of transmission, clinical manifestations, precautions, prevention and clinical management should be included in the syllabi for both dental and auxiliary courses.

Health education programs should help in spreading awareness about AIDS among health care provider's including dentists and auxiliary staff for clearing the misconceptions and beliefs regarding the routes of transmission which otherwise perpetuates wrong messages in community resulting in discrimination and stigmatization of such patients and denial in their treatment.

\section{ACKNOWLEDGEMENTS}

Authors are grateful to all the participants for extending their cooperation and support throughout the study.

Funding: No funding sources

Conflict of interest: None declared

Ethical approval: The study was approved by the Institutional Ethics Committee

\section{REFERENCES}

1. Cohen LA, Romberg E, Grace EG, Barnes DM. Attitudes of advanced dental education students toward individuals with AIDS. J Dent Educ. 2005;69:896-900.

2. UNDP in India: Results from 2010. Empowered lives. Resilient nations. Available at: http://www.undp.org.in/ sites/ default/ files/reportsublication/ UNDP_Annual_Report_ 2011.pdf

3. Swaminathan S, Narendran G. HIV and tuberculosis in India. J Biosci. 2008;33:527-37.

4. Cohen LA, Romberg E, Grace E. Revisiting the attitudes of dental faculty toward individuals with AIDS. J Dent Edu. 2001;65:249-52.

5. Zhang X, Reichart PA, Song Y. Oral manifestations of HIV/AIDS in China: a review. Oral Maxillofac Surg. 2009;13(2):63-8.

6. Patel BH, Srivastava RK, Moitra M. Knowledge on HIV/AIDS among Healthcare Professionals in Surat City. Int J Int Med Res. 2015;2(3):6-9.

7. Erasmus S, Luiters S, Brijlal P. Oral Hygiene and dental student's knowledge, attitude and behaviour in managing HIV/AIDS patients. Int J Dent Hyg. 2005;3:213-7.

8. ICMR Bulletin. Live and Let live: acceptance of people living with HIV/AIDS in the era where stigma and discrimination persist. 2002;32(11\&12):104-12.
9. Oliveira ER, Narendran S, Falcão A. Brazilian dental students' knowledge and attitudes towards HIV infection. AIDS Care. 2002;14:569-76.

10. Islam MT, Mostafa G, Bhuiya AU, Hawkes S, de Francisco A. Knowledge on, and attitude toward, HIV/AIDS among staff of an international organization in Bangladesh. J Health Popul Nutr. 2002;20:271-8.

11. WHO. Research Package: Knowledge, Attitude, beliefs and practices on AIDS (KABP) phase I. WHO Geneva. 1990.

12. Rasania SK, Singh RN. HIV/AIDS: an evaluative study among health care providers. Indian Journal of Sexually Transmitted Diseases. 2003;24(2):58-61.

13. Omisakin FD. Nurses' knowledge and skills about caring for patients with HIV/AIDS in Osun state. Niger J Med. 2001;10(1):30-3.

14. Chauhan AS, Hussain MA, Patil S, Nallala S, Mishra J. Knowledge and attitudes related to HIV/AIDS among medical and Allied health Sciences Students. Indian J Community Health. 2011;23(2):96-8.

15. Mohsin S, Nayak S, Mandaviya V. Medical students' knowledge and attitudes related to HIV / AIDS. Nat J Com Med. 2010;1(2):146-9.

16. Khosravanifard B, Rakshan V, Ghasemi M, Pakdel A, Baradaran-Eghbal S, Sheikholeslami R, et al. Tehran dentists self-reported knowledge and attitudes towards HIV/AIDS and observed willingness to treat simulated HIV-Positive patients. East Mediterr Health J. 2012;18(9):928-34.

17. Patil P, Sreenivasan V, Goel A. Knowledge of HIV/AIDS and attitude of dental students towards HIV/AIDS patients: A cross sectional survey. J Education and Ethics in Dentistry. 2011;1(2):59-63.

18. Kitaura H, Adachi N, Kobayashi K, Yamada T. Knowledge and attitudes of Japanese dental health care workers towards HIV-related disease. J Dent. 1997; 25:279-83.

19. Sadeghi M, Hakimi H. Iranian dental students' knowledge of and attitudes towards HIV/AIDS patients. J Dent Educ. 2009;73:740-5.

20. Bishop GD, Oh HML, Swee HY. Attitudes and Beliefs of Singapore Health Care Professionals Concerning HIV/AIDS. Singapore Med J. 2000;41(2):55-63.

21. Goel NK, Kaur N, Singh SP, Singh G, Kaur P. An explorative 'KABP' study on AIDS among nursing professionals. Indian J. Prev. Soc. Med. 1999;30(2):79-84.

22. Uti OG, Agbelusi GA, Jeboda SO, Ogunbodede E. Infection control knowledge and practices related to HIV among Nigerian dentists. J Infect Dev Ctries. 2009.

23. McCarthy GM, Ssali CS, Bednarsh H, Jorge J, Wangrangsimakul K, Page-Shafer K. Transmission of HIV in the dental clinic and elsewhere. Oral Dis. 2002;8 Suppl 2:126-35.

24. Bell DM, Shapiro CN, Ciesielski CA, Chamberland ME. Preventing blood borne pathogen transmission 
from health-care workers to patients. The CDC perspective. Surg Clin North Am. 1995;75(6):1189203.

25. Dickinson GM, Morhart RE, Klimas NG, Bandea CI, Laracuente JM, Bisno AL. Absence of HIV transmission from an infected dentist to his patients. An epidemiologic and DNA sequence analysis. JAMA. 1993;269(14):1802-6.

26. McCartan BE, Samarnayake LP. Oral care of HIV infected patients: The knowledge and attitude of Irish dentists. J Ir Dent Assoc. 1991;37(2):41-3.

27. Ryalat ST, Sawair FA, Shayyab MH, Amin WM. The knowledge and attitude about HIV/AIDS among Jordanian dental students: (Clinical versus pre clinical students) at the University of Jordan. BMC Res Notes. 2011;4:191.

28. Daniel M. Aids in India: Denial and disaster. Harv Int Review. 2003;25:9-10.
29. Anjum Q, Siddiqui H, Ahmed Y, Rizvi SR, Usman Y. Knowledge of students regarding hepatitis and HIV/AIDS of a private medical university in Karachi. J Pak Med Assoc. 2005;55:285-8.

30. Chatterjee G, Chakraborthy I, Mitra J. Knowledge about HIV and AIDS among medical entrants-A questionnaire study. Indian $\mathbf{J}$ Dermatol. 2001;46(2):80-2.

31. WHO/GPA/SBR. Interview Schedule on Knowledge, Attitudes, Beliefs and Practices on AIDS/KABP Survey. 1988.

Cite this article as: Yousuf $\mathrm{A}$, Shah AF, Jan SM, Sidiq M, Baba IA. Awareness of HIV/AIDS infection and ethical concerns amongst dentistry students and auxiliary staff in a hospital setup in Kashmir, India. Int J Community Med Public Health 2016;3:2850-5. 